\title{
KONTESTASI NEGARA DI TENGAH PANDEMI COVID-19
}

\author{
Sukma Sushanti \\ Program Studi Hubungan Internasional \\ Fakultas Ilmu Sosial dan Ilmu Politik \\ Universitas Udayana \\ sukmasushanti@gmail.com
}

\begin{abstract}
ABSTRAK
International disease menjadi permasalahan transnasional yang telah memperkaya kajian dalam hubungan internasional. Hal tersebut direfleksikan oleh kondisi Pandemi COVID-19 yang saat ini menjadi perhatian dunia, yang kemudian menempatkan politik dan kesehatan menjadi sebuah keniscayaan. Hal itulah yang menjadi tujuan utama dari penelitian ini, untuk memberikan gambaran bahwa isyu kesehatan menjadi salah satu hal yang tidak terhindarkan dari permainan kepentingan banyak negara. Studi kepustakaan memperkuat justifikasi terkait isyu kesehatan dan politik internasional sebagai bagian integral dari hubungan interaksi antara aktor. Eksekusi kebijakan luar negeri mulai menggunakan isyu kesehatan sebagai salah satu agenda politik di arena internasional, dan seringkali hal tersebut menciptakan persaingan antar negara. Kondisi ini didukung dengan adanya pergeseran tatanan global dalam konstelasi politik internasional sebagai implikasi dari pandemic COVID-19.
\end{abstract}

Kata kunci: international disease, hubungan internasional, pandemi COVID-19, isu kesehatan. kebijakan luar negeri

\begin{abstract}
International disease become the transnational issue that has enriched the studies in International Relations. It refers to the recent situation of COVID-19 pandemic, which is currently become the global concern. Then, politics and health interlinked each other. The main objective of the research to describe and explain about health issue is inevitable in demonstrating state interest. Desk research based on the valid sources helped build justification that health and international politics become integral part of the relation beween the actors. The scope of state foreign policy already adopt the health issues as the one of important agenda, in which created the competition in the international field. This condition supported by the shifting of the global order in the international politic constellation as the implication of COVID-19 pandemic.
\end{abstract}

Keyword: international disease, international relation, COVID-19 pandemic, health issues. Foreign policy 


\section{PENDAHULUAN}

Pandemi COVID-19 membuat roda ekonomi di seluruh negara berdenyut lemah, tidak mengenal skala power yang melekat padanya, baik besar, menengah, ataupun kecil. Saat ini dunia tengah berhadapan dengan ancaman musuh yang sama dan tidak kasat mata, sehingga membuat protokol kesehatan pun harus diterapkan di setiap tempat, guna menciptakan ketahanan negara yang mapan, terutama ditujukan untuk melindungi warga negara yang merupakan salah satu elemen power yang signifikan. Banyak analisis yang mengemuka terkait dengan terjadinya pandemi COVID-19 ini, dimulai dari telaah bidang kesehatan, bahwa jenis penyakit menular yang menyerang sistem pernapasan manusia ini bukanlah sebuah penyakit baru, namun berasal dari virus corona yang telah bermutasi dan menjadikan sifatnya semakin ganas dengan penularan yang cepat, terutama ketika mengenai manusia yang telah memiliki penyakit bawaan. Namun hal yang lebih penting untuk diperhatikan, bahwa isyu pandemi penyakit juga memberikan dampak terhadap konstelasi politik internasional.

\section{HASIL DAN PEMBAHASAN}

\section{Pandemi COVID-19: Sekuritisasi Dunia}

Pandemi ini sering dikaitkan dengan gaya berperang dengan menggunakan isyu sebagai alat untuk menyudutkan pihak lain, atau dikenal dengan istilah proxy war. Aktor negara maupun non-negara saling membentuk aliansi untuk menyuarakan kecemasan dan urgensi guna merumuskan langkah bersama untuk melakukan tindakan nyata yang menyelesaikan kasus ini dengan cepat dan tepat. Pandemi menjadikan kesehatan sebagai isyu yang esensial untuk diagendakan oleh negara dalam perumusan kebijakan luar negerinya di masa sekarang. Hal ini semakin memperkuat justifikasi bahwa isyu yang bersifat low politic, seperti contohnya pandemi COVID-19 menjadi hal yang bersifat lintas batas negara, dan telah memperluas kajian dalam keilmuan Hubungan Internasional (Stoeva, 2019).

Sejatinya, isyu yang terkait wabah penyakit seperti pandemi COVID-19 ini, telah sejak abad 19 menjadi isyu transnasional, sehingga pada saat itu dibentuklah lembaga kesehatan dunia (WHO) untuk memberikan tata aturan global yang mampu memberikan solusi dalam penanganan isyu tersebut (Stoeva, 2019). Namun seperti yang telah dijelas pada bagian sebelumnya, bahwa hubungan internasional menempatkan isyu wabah panyakit menjadi salah satu fokus kajiannya pada tahun 1990an (Stoeva, 2019), karena melihat dampak luas akan keterlibatan aktor-aktor di dalamnya, tidak hanya negara, namun organisasi internasional, bahkan tokoh penggiat filantropi internasional, memberikan peran yang signifikan terkait berkembangnya isyu ini menjadi agenda politik internasional. Bahkan, pada pertemuan putaran Organisasi Perdangan Dunia (WTO) di Marrakesh pada tahun 1994, isyu kesehatan menjadi salah satu agenda yang dibicarakan secara intensif pada saat itu, hal ini terkait bahwa ekonomi global bisa terdampak oleh fenomena pandemi penyakit (Stoeva, 
2019). Sekaligus memberikan peluang akses pasar bagi bidang perdagangan jasa kesehatan (terkait akses dan fasilitas) dan farmasi internasional yang tentunya akan memberikan pendapatan ekonomi yang strategis bagi banyak negara (Stoeva, 2019). Meskipun demikian hal itu menimbulkan polemik, karena dunia kesehatan banyak didominasi oleh perusahaan yang berasal dari negara maju, bahkan persaingan dagang dalam bidang industri kesehatan, seringkali mempertajam konflik antar negara. Bercermin dari kondisi ini, maka tidaklah mengherankan jika isyu pandemi pun memberikan kontribusi pada isyu keamanan internasional, terutama bersignifikansi terhadap berlangsungnya proses sekuritisasi.

Hal serupa pernah terjadi pasca kejadian terror bom 911, saat itu Amerika Serikat adalah negara yang sangat intensif menggelontorkan isyu globar war on terror, momentum itu sekaligus menjadi justifikasi bahwa ancaman keamanan dunia tidak lagi disebabkan peperangan antar negara namun berkembang ancaman yang berasal dari organisasi teroris yang terorganisir. Dan dunia pun menjadi tersekuritasasi oleh isyu yang dimobilisasi oleh aktor negara dan diperkuat oleh peran media yang meyakinkan publik dunia (Buzan,dkk, 1998) bahwa isyu terorisme adalah pekerjaan bersama. Terkait dengan hal tersebut, saat ini dunia telah tersekuritisasi oleh isyu pandemi COVID 19, yang menarik dari kondisi terkini adalah pengidentifikasian aktor utama yang mempropagandakan isyu penyakit ini tidak mudah untuk dipetakan, karena seluruh dunia merasakan akibat seriusnya. Namun, peran media menjadi satu elemen yang tidak dapat dinafikan peranannya membuat kondisi dunia terasa mencekam, sehingga seluruh negara menerapkan protokol kehidupan normal baru atau yang dikenal dengan new normal untuk sekedar menghidupkan pundi-pundi perekonomiannya secara perlahan.

Dalam kasus pandemi COVID 19 yang telah menciptakan fenomena sekuritisasi di seluruh negara, Cina adalah aktor negara yang dianggap paling bertanggungjawab atas kondisi yang terjadi saat ini. Sebuah fakta yang tidak dapat disangkal bahwa pandemi ini bermula atas wabah yang terjadi di Wuhan, Cina, ketika sebuah protokol kesehatan dianggap telah gagal diterapkan dalam laboratorium penelitian virus di negara tersebut (Kumar, 2020). Meskipun fakta telah berbicara, hal ini tidak lantas membuat Cina gentar dalam politik luar negerinya yang tampak ambisius, dan semakin nyata terlihat ketika pandemi ini merebak di seluruh dunia. Bahkan Uni Eropa dan Amerika Serikat dibuat kewalahan dengan kejadian pandemic yang telah banyak menyerap anggaran belanja negara. Sehingga tidak disangsikan, bagaimana negara-negara di kawasan selatan dunia yang sebagian besar adalah kategori negara berkembang berjuang untuk mengatasi persoalan ini, baik dari sisi ekonomi, sampai dengan kedaulatannya.

Kondisi yang menggambarkan kepanikan di banyak negara pada saat ini, semakin memberikan gambaran bahwa ancaman tidak lagi berasal dari sesuatu yang kasat mata, namun dapat berasal sebuah organisme yang berukuran mikromilimeter, yang memberikan implikasi serius terhadap seluruh sektor kehidupan manusia. Banyak negara di Eropa bahkan Amerika Serikat dibuat tidak siap ketika pandemi ini muncul. Sistem perangkat kesehatan di negara maju pun dibuat kewalahan bahkan tidak 
berdaya, karena pandemic menimbulkan korban jiwa dalam jumlah masif dalam waktu yang bersamaan. Pandemi ini telah menyita anggaran belanja di banyak negara yang harus dialihkan, dan kemudian dialokasikan untuk penanganan COVID-19. Dampak dari pandemi ini memberikan dampak terhadap keberlangsungan human capital secara serius, meskipun negara mempunya keberlimpahan sumber daya alam atau bahan baku industri namun hal ini tidak memberikan signifikansi yang benefisial bagi negara, karena mobilitas manusia dihentikan oleh pandemi ini (Fairman, dkk, 2012). Daya beli masyarakat dunia pun merosot secara tajam, jika kondisi ini berlangsung lebih jauh lagi maka akan menimbulkan resesi dunia, selain itu angka mortalitas yang tinggi akan menyebabkan hilangnya sebagian besar populasi dunia.

Situasi pandemi ini kemudian akan memberikan kontribusi bagi para elit di seluruh dunia, untuk kembali menempatkan potensi ancaman kesehatan manusia sebagai agenda penting dalam politik luar negerinya (Fairman, dkk, 2012). Hal ini kemudian memberikan justifikasi dan kembali membuka perdebatan, bahwa aksi kolektif menjadi sebuah hal yang dipertanyakan urgensinya, karena negara akan lebih berfokus pada kebutuhan domestiknya, ketimbang memperjuangkan pihak lain. Sehingga, fenomena deglobalisasi mengemuka saat ini, bahwa arena multilateral tidak lagi dipandang menjadi forum yang strategis bagi banyak negara untuk menemukan solusi dari permasalahan seperti pandemi ini. Salah satu contoh dari hal itu adalah keputusan Amerika Serikat yang menyetop pendanaannya untuk WHO yang bernilai sekitar 500 juta dolar Amerika atau 7.8 triliun rupiah per tahun, dan hal ini dilakukan oleh Amerika Serikat karena mengganggap lembaga tersebut tidak cakap atau lambat terkait isyu pandemi COVID-19 (liputan 6.com, 2020). Meskipun keputusan tersebut menimbulkan pertentangan baik di kalangan Amerika Serikat sendiri, ataupun dunia internasional, karena pendanaan tersebut penting untuk riset medis pandemi COVID19 (liputan 6.com, 2020).

\section{Kapitalisasi Politik Luar Negeri dalam Konteks Global Health}

Ketidakcakapan WHO dalam merespon secara cepat pandemi COVID 19 menjadi sebuah kesangsian terhadap organisasi kesehatan dunia ini yang terkait dengan peran dan fungsinya. Meskipun mekanisme International Health Regulation (IHR) yang telah dirumuskan sejak lama di WHO, bahkan pada tahun 2005 dilakukan pembaharuan terhadap regulasi tersebut, seharusnya bisa menjadi pedoman bagi organisasi ini untuk dapat informasi yang lugas bagi dunia (Davies, 2019). Selain itu tujuan dari dibuatnya IHR ini untuk memberikan asistensi dan rekomendasi bagi negara terkait dengan pelayanan kesehatan di setiap negara. Sayangnya hal itu tidak dijumpai dalam kondisi Pandemi Covid 19, sehingga berakibat diputusnya pendanaan oleh donatur terbesar, Amerika Serikat, untuk WHO.

Kalkulasi rasionalitas banyak dilakukan oleh negara dalam situasi pandemi ini, salah satu contohnya adalah tindakan Amerika Serikat yang telah dijelaskan pada bagian sebelumnya. Dalam konteks keputusan Amerika Serikat tersebut terjadi, karena negara melihat bahwa sebagai donor terbesar WHO, harapannya lembaga tersebut akan lebih memberikan prioritas atau perhatian terhadap negara tersebut, sejatinya negara 
akan selalu mengedepankan keuntungan, sehingga negara bersifat sebagai aktor yang uniter (Mintz,2010). Meskipun kebijakan tersebut akan mengesampingkan banyak suara baik dari domestik atau pun respon dari dunia internasional. Dan seringkali dampak dari sebuah keputusan negara akan memukul dirinya sendiri, namun terlepas dari itu semua keputusan sebuah negara seringkali ditujukan untuk memperlihatkan kapasitas power yang dimiliki terhadap pihak lain (Mintz, 2010).

Kapitalisasi politik luar negeri yang dilakukan oleh masing-masing negara di tengah masa pandemi ini menjadi sebuah fenomena yang tak terelakan. Kelompok negara berkembang, termasuk Indonesia di dalamnya, mengaktifkan secara intensif Gerakan Organisasi Non-Blok menjadi suatu pilihan yang strategis. Dengan bersikap 'netral' akan lebih mudah bagi kelompok negara ini untuk mendapatkan dukungan dari pihak barat (Amerika Serikat dan sekutunya), sekaligus mendapatkan manfaat dari pihak timur (Cina dan sekutunya). Terlebih dalam pandemi ini semakin mengukuhkan bahwa global health menjadi satu instrumen politik, karena kondisi ini juga membuat pemetaan negara dengan kapital kuat dan berkembang menjadi jelas, tentunya memakai indikator kapasitas kesehatan publik yang dimiliki oleh negara (McInnes dan Lee, 2012). Sehingga kapitalisasi politik luar negeri yang dilakukan oleh banyak negara adalah untuk memperoleh dukungan dalam membangun kapasitas dalam bidang kesehatannya. Seperti yang telah pada bagian sebelumnya, bahwa kesehatan manusia adalah suatu keniscayaan yang harus menjadi perhatian dalam perumusan kebijakan luar negeri suatu negara, mengingat implikasinya terhadap siklus perekonomian dan sosial dari sebuah negara sangatlah signifikan. Terlebih lagi akan berpengaruh juga pada hubungan antar negara dalam jangka panjang.

Global Health menjadi sebuah tren yang memandang bahwa persoalan wabah penyakit tidak lagi menjadi persoalan domestik suatu negara, dan transisi wabah penyakit yang semula bersifat low politics bisa kemudian dianggap sebagai persoalan yang bisa memberikan dampak signifikan bagi sektor-sektor strategis suatu negara. Terlebih jauh lagi ketika global health menjadi satu unsur yang esensial untuk negara mencapai kepentingannya melalui politik luar negeri dan diplomasi, serta keterkaitannya dengan ekonomi, bahkan pertahanan negara (McInnes dan Lee, 2012). Dalam konteks pandemi COVID-19, negara maju yang secara intensif terus melakukan manuvernya untuk memposisikan diri mereka sebagai pihak yang akan memberikan solusi bagi persoalan ini, meskipun mereka sendiri mengalami persoalan domestik yang cukup serius yang diakibatkan oleh kondisi wabah ini. Tak pelak lagi setiap negara maju menunjukan power mereka dengan menampilkan data anggaran yang akan dialokasikan pada penanganan pandemi COVID-19. Sehingga data numeric nominal anggaran dapat dimaknai sebagai alat untuk menunjukan seberapa besar kapasitas power yang dimiliki. Persaingan negara yang mengarah pada ketegangan pun terjadi di tengah situasi pandemi ini, seperti ketegangan antara Turki dan Spanyol terkait suplai masker (BBC.com, 2020). Berbagai ketegangan terjadi tidak hanya antar negara, tuduhan Amerika Serikat terhadap WHO yang dianggap lebih Cina-sentris saat ini, hal ini merujuk pada lemahnya sistem pengawasan kesehatan pada lembaga ini (BBC.com, 2020). Selain itu solidaritas negara-negara Uni Eropa juga menghadapi pertaruhan 
yang tidak kalah sengitnya terkait mekanisme penanganan dampak pandemi ini, sehingga menyebabkan beberapa negara pada organisasi supra nasional tersebut tampak lebih berdekatan dengan pihak lawan (Cina) (BBC.com, 2020)

\section{Fragmentasi Kekuatan Dunia}

Konstelasi politik global akan mengalami banyak perubahan sebagai implikasi dari Pandemi COVID-19, mulai dari pemetaan kekuatan negara dan aliansinya, sampai dengan arah politik luar negeri banyak negara. Pandemi COVID 19 akan membuat terjadinya pergeseran kekuatan global yang semula Amerika Serikat dan Eropa dianggap sebagai poros utama dari barat, sekarang perlahan bergeser pada poros timur, yakni Singapura dan Korea Selatan, termasuk Cina didalamnya (Syawfi dalam Jurnal Ilmiah Hubungan Internasional, 2020). Poros barat dianggap gagal dalam memberikan respon tepat guna pada saat pandemic COVID 19 terjadi, dilain pihak Cina yang dianggap melakukan kesalahan yang menyebabkan terjadinya pandemic ini mulai menunjukan respon yang lebih baik (Syawfi dalam Jurnal Ilmiah Hubungan Internasional, 2020), bahkan Cina berperan signifikan dalam kerjasama pengadaan alat-alat medis di banyak negara. Kerjasama dalam bidang riset kesehatan juga sedang intensif dilakukan oleh Cina.

Nuansa nasionalisme yang mendominasi wajah banyak negara pada saat ini, sehingga negara akan lebih mengedepankan untuk bekerja sama dengan pihak-pihak yang bisa memberikan dukungan yang menguntungkan bagi kondisi domestiknya yang saat ini terdampak pandemic COVID 19. Sehingga collective problem tidak dipandang sebagai suatu keniscayaan di tengah situasi internasional yang konfliktual, meskipun pandemi ini menjadi persoalan global, namun setiap negara akan berusaha memperkuat kapasitasnya masing-masing untuk bertahan di tengah pandemi ini. Sehingga menurut Sophia Gaston, teori telah terbantahkan, bahwa ketika semua negara menghadapi persoalan yang sama, seharusnya peluang untuk kerjasama pun semakin intensif, Namun hal itu bertolak belakang dengan situasi pandemi ini. Setiap negara lebih mengedepankan untuk memaksimalkan dalam perolehan kepentingannya meskipun harus dilakukan secara kerjasama, yang artinya kepentingan nasional adalah sebuah keniscayaan yang tidak terbantahkan (BBC.com, 2020).

Konstelasi politik global meskipun mengalami pergeseran akibat terjadinya pandemi COVID 19 yang kemudian membuat arah politik luar negeri harus beradaptasi dengan kondisi tersebut, namun satu hal yang perlu digarisbawahi adalah tatanan global masih berpijak pada hegemoni dan dominasi. Meskipun de-globalisasi menjadi fenomena saat ini, sebagian kalangan berpendapat bahwa mekanisme multilateral dapat menjadi pilihan bagi negara untuk segera menyusun mekanisme penyelesaian dari kondisi pandemi COVID 19 (Kumar dalam Daily Pioneer.com, 2020). Tentunya ini menjadi justifikasi bagi beberapa negara untuk menjadi hegemon bagi yang lain. Seperti yang telah dijelaskan pada bagian sebelumnya, bahwa pandemi semakin mempertegas kubu barat dan timur serta aliansi yang kemudian terbentuk diantara keduanya. Meskipun terdapat tantangan tersendiri ketika mengkolaborasikan antara kesehatan dan politik internasional, untuk kemudian dapat membangun benang 
merahnya bahwa antara kedua elemen tersebut bisa saling terkait satu sama lain (Stoeva, 2016). Situasi pandemi inilah yang kemudian memberikan pembuktian ketika bahwa isyu kesehatan bisa memberikan perubahan besar dalam hubungan internasional, karena pandemi harus lebih menekankan pada pendekatan etis ketimbang dengan pendekatan yang bersifat militeristik (Fairman, dkk, 2012).

Kondisi dunia di tengah pandemi COVID-19 ini memberikan tantangan bagi banyak negara berkembang yang harus membangun ketahanan kesehatannya ditengah melesunya roda perekonomian mereka, baik dalam bidang jasa layanan kesehatan, ataupun infrastruktur medis. Sehingga berkoalisi akan menjadi satu pilihan yang paling rasional bagi negara untuk dilakukan (Fairman dkk, 2012), meskipun demikian mengedepankan kepentingan nasional menjadi satu hal yang bersifat mutlak bagi setiap negara yang masuk dalam putaran diplomasi kesehatan. Kelompok negara barat pun mengedepankan sikap state centric yang kental ditengan situasi pandemi ini, mereka pun kerap merangkul media dan organisasi internasional untuk melakukan gerakan solidaritas yang bersifat memojokan Cina yang dianggap sebagai musuh bersama saat ini. Meskipun demikian fragmentasi hubungan diplomatik diantara negara-negara barat pun terjadi, solidaritas menjadi domain bagi sebagian negara maju (Amerika Serikat, Inggris, Jerman, Perancis beserta sekutunya di Asia) untuk memperkuat posisi mereka sebagai hegemon dari pihak lain. Sementara itu kekuatan Cina dan Rusia, serta aliansinya semakin terlihat jelas.

Eksekusi politik luar negeri Cina melalui One Belt, One Road (OBOR) semakin intensif. Pada awal merebaknya pandemi COVID-19, citra Cina melemah karena dianggap sebagai sumber bencana dunia ini, namun seiring dengan waktu ia mulai menunjukan itikadnya dengan menawarkan mekanisme bantuan kesehatan ke banyak negara termasuk Eropa. Selain itu Cina intensitas dukungannya terhadap negara yang sedang berkonflik, terutama negara yang menjadi musuh bagi barat dan aliansinya. Salah satu contohnya, yakni Cina saat ini memberikan dukungan kapasitas militer Pakistan sebagai bentuk responnya atas konflik perbatasan dengan India. Politik kesetimbangan pun ditempuh India dengan melakukan propaganda politik lewat Indic belt-nya. India menyuarakan suara kelompok negara yang dianggap telah mengalami kerugian akibat eksistensi OBOR - Cina, ditambah dengan isyu pandemi dijadikan sebagai rujukan kuat untuk semakin memojokan Cina.

Indonesia sendiri sebagai salah satu negara kuat di kawasan menunjukan sikap yang cenderung imparsial terhadap Cina ataupun pihak barat. Hal ini dilakukan Indonesia untuk semakin memperteguh posisinya sebagai negara yang menganut politik luar negeri bebas aktif. Sebagai satu-satunya negara di kawasan yang menjadi anggota tetap pada forum G20, pilihan Indonesia merupakan hasil kalkulasi rasionalitas agar terobosan penyelesaian pandemi COVID-19 segera terwujud. Posisi Indonesia yang dinilai ambigu ini justru menimbulkan polemik domestik di dalam negara. Sikap Indonesia yang terbuka terhadap kerjasama dengan banyak negara, termasuk intensitas kerjasamanya dengan Cina yang cukup erat telah banyak menuai kritik dari berbagai kalangan, baik itu dari domestik atau pun internasional. Kritik yang kerap diberikan adalah bahwa hubungan bilateral antara Cina dan Indonesia, dinilai tidak seimbang. 
Selama ini Indonesia hanya bergantung pada komoditas primer (bahan mentah) untuk komoditas ekspornya ke Cina, sementara itu impor yang masuk adalah komoditas manufaktur yang mempunyai nilai jual lebih tinggi. Selain itu juga, meski Cina adalah salah satu mitra strategis bagi ASEAN sejak lama, termasuk Indonesia di dalamnya, bahkan Cina juga masuk dalam mekanisme ASEAN Regional Forum, tidak lantas membuatnya lebih transparan pada pihak eksternal terutama terkait dengan kapasitas pertahanan (Sinaga, 2018). Hal itu menjadi sebuah kontradiksi, mengingat kerangka kerja dari pembentukan ARF adalah untuk merumuskan hal-hal yang terkait dengan pertahanan (Sinaga, 2018).

Hal terkini yang menjadi sorotan adalah membanjirnya tenaga kerja Cina di Indonesia, dan kebanyakan dari mereka adalah pekerja tanpa keahlian (Sinaga, 2018). Fenomena itu jika dibiarkan akan menjadi penyebab angka pengangguran yang tinggi dan meningkatnya kemiskinan di Indonesia. Terlepas dari problematika terkait hubungan antara Indonesia dan Cina, merujuk kembali pada prinsip politik luar negeri bebas dan aktif, sehingga hubungan tersebut dinilai tidak mengingkari imparsialitas Indonesia dalam menjalin hubungan diplomatik dengan pihak manapun (Sinaga, 2018). Termasuk di tengah masa pandemi COVID 19, Indonesia kembali intensif bekerja sama dengan Cina dalam kegiatan riset uji coba vaksin yang akan segera diluncurkan pada awal tahun 2021. Meski sebuah pelajaran terkait bantuan atau investasi Cina harus ditelaah dengan seksama, hal itu terjadi ketika Itali mengembalikan sejumlah alat kesehatan ke Cina karena tidak sesuai standar baku internasional. Oleh karena itu Uni Eropa menuntut Cina untuk memberikan ganti rugi karena keteledoran yang telah dilakukan, sehingga membuat dunia mengalami pandemi Covid 19.

Pandemi COVID 19 memberikan sebuah gambaran akan pentingnya menginfiltrasikan isyu kesehatan dalam kebijakan luar negeri, seperti yang telah dibahas pada bagian sebelumnya. Mengingat implikasi kesehatan terhadap sektorsektor vital negara, seperti ekonomi sampai dengan pertahanan. Ketika isyu kesehatan telah tercakup dalam prioritas kebijakan luar negeri, maka negara mempunya kesiapan yang terkait dengan mitigasi bencana wabah atau pandemi ketika terjadi (Kickbusch dkk, 2013). Selain itu pandemi ini menyebabkan pergeseran dalam konstelasi politik internasional, eksistensi selatan-selatan semakin intensif, dimana negara rising power dianggap lebih bisa diandalkan untuk menjadi mitra dalam menyelesaikan berbagai persoalan, termasuk isyu kesehatana (Kickbusch dkk, 2013). Terlebih dengan dunia saat ini yang mengalami polarisasi kekuatan politik, hal itulah yang menstimulasi intensitas aliansi selatan-selatan semakin kokoh, dimana terdapat Brazil dan Afrika Selatan, serta aliansi negara yang berlandaskan ideologi yang sama, seperti Cina, Kuba, Rusia. Forum selatan-selatan dianggap mampu menyuarakan kepentingan negara berkembang secara lebih proporsional, ketimbang dengan forum utara-selatan (Kickbusch, dkk, 2013). Pergeseran inilah yang akan membuat dunia harus melakukan banyak penyesuaian tidak hanya yang bersifat kenegaraan, sampai dengan setiap individu harus mampu untuk dapat mengakomodir perubahan kehidupan pasca pandemi. 


\section{SIMPULAN}

De-globalisasi menjadi suatu hal yang saat ini dihadapi oleh banyak negara, ketika dunia berhadapan dengan ancaman pandemi COVID-19. Hal itu menyebabkan pergeseran tatanan global, terutama yang terkait dengan pemetaan kekuatan politik internasional. Kelompok negara maju yang berada di bagian utara dunia, harus menghadapi kenyataan bahwa mereka harus mempersiapkan diri untuk melakukan penyesuaian pasca pandemi. Terlebih eksistensi forum Selatan-Selatan semakin jelas dengan dukungan negara besar, seperti Cina dan Rusia, yang selama ini kerap berseberangan dengan kelompok negara utara. Selain itu, pandemic COVID-19 semakin mengukuhkan justifikasi bahwa isyu kesehatan tidak dapat dinafikan dari komponen esensial dalam setiap kebijakan luar negeri.

\section{Referensi}

Buzan, Barry, Ole Waever, Jaap de Wilde. Security: A New Framework for Analysis. United States of America: Lynne Rienner Publisher Inc., 1998

Davies, Sara E. Containing Contagion: The Politics of Disease Outbreak in Southeast Asia. United States of America: John Hopkins University Press, 2019

Duarte, Fernando. Diplomasi Virus Corona: Bagaimana Covid-19 Memicu Ketegangan Internasional Karena Pil, Masker, dan Berbagai Macam Tuduhan. 2020. Diunduh melalui https://www/bbc.com/indonesia/dunia/52240043

Fairman, David, Diana Chigas, dkk. Negotiating Public Health in A Globalized World: Global Health Diplomacy in Action. New York: Springer, 2012

Jha, Gautam Kumar. Pandemi: Penyebab dan Otot Kekuatan Besar. 2020. Diunduh melalui: $\quad$ https://liputan4.com/pandemi-penyebab-dan-otot-kekuatan-besar diakses pada 29 Juni 2020

Jha, Gautam Kumar. A Multilateral Global Order Need of The hour. 2020. Diunduh melalui https://www.dailypioneer.com/2020/columnist/a-multilateral-globalorder-need-of-the-hour.html diakses 30 Juni 2020

Kickbusch, Ilona, Graham Lister, dkk. Global Health Diplomacy: Concepts, Issues, Actors, Fora, and Cases. New York: Springer, 2013

Kurnia, Tommy. Donald Trump Stop Dana Untuk WHO, Keputusan Berbahaya Saat Pandemi Corona?. 2020. Diunduh melalui https://www.liputan6.com/global/read/4229179/headline-donald-trump-setopdana-untuk-who-keputusan-berbahaya-saat-pandemi-corona diakses pada tanggal 23 Juli 2020

Mintz, Alex, Karl DeRouen Jr. Understanding Foreign Policy Decision Making. New York: Cambridge University Press, 2010 
McInnes, Colin, Kelly Lee. Global Health and International Relations. United Kingdom: Polity Press, 2012

Sinaga, Lidya Christin. Six Decade Indonesia -China Relations: An Indonesian Perspectives. Jakarta: LIPI Press, 2018

Stoeva, Preslava. Interational Relations and Global Politics of Health: A State of Art. 2016. Diunduh melalui https://www.researchgate.net/publication/315839340 diakses pada 10 Juli 2020

Syawfi, Idil. Implikasi Pandemi Covid-19 Terhadap Hubungan Internasional: Menuju Dunia Paska Liberal. 2020. Diunduh melalui http://journal.unpar.ac.id/index.php/jurnalIlmiahHubunganInternasional/articl e/view/3864 diakses pada 20 Juli 2020 